\title{
PENGARUH PEMBERIAN POSISI SEMIFOWLER DAN TEKNIK PURSED LIPS BREATHING TERHADAP SATURASI OKSIGEN PADA PASIEN PPOK DI RUANG HCU RSD MANGUSADA
}

\section{The Effect of Semi Fowler Positioning and Pursed Lips Breathing Technique on Oxygen Saturation of Patients with COPD in HCU Ward Mangusada Hospital Badung Regency}

\author{
Ni Made Devi Hariska Milasari, Komang Yogi Triana
}

\author{
STIKes Bina Usada Bali
}

\section{Riwayat artikel}

Diajukan: 4 maret 2021

Diterima: 11 Maret 2021

\section{Penulis Korespondensi: \\ - Ni Made Devi Hariska Milasari \\ - STIKes Bina Usada bali}

e-mail:

hariska.mila@gmail.com

\section{Kata Kunci:}

posisi semifowler, teknik pursed lips breathing, PPOK

\section{Abstrak}

PPOK merupakan penyakit pada saluran pernafasan yang memiliki gejala adanya produksi sputum, sesak napas dan batuk yang produktif. Posisi semifowler dan pursed lip breathing membuat oksigen di dalam paru-paru semakin meningkat sehingga lebih mudah untuk bernafas dan mengurangi kerusakan membrane alveolus akibat tertimbunnya cairan. Tujuan penelitian ini untuk mengetahui pengaruh pemberian posisi semifowler dan teknik pursed lips breathing terhadap saturasi oksigen pasien dengan PPOK.

Penelitian ini merupakan penelitian kuantitatif Pre-Experimental design, dengan rancangan One - Group Pretest-Posttest Design. Sampel penelitian menggunakan teknik Non Probabilty Sampling yaitu Consecutive Sampling dengan jumlah sampel 30 orang. Kemudian dilanjutkan dengan uji Wilcoxon Signed Ranks Test untuk menguji hipotesis. Berdasarkan hasil penelitian didapatkan rata-rata saturasi oksigen pasien sebelum pemberian posisi semifowler dan teknik pursed lips breathing adalah $93.10 \%$, saturasi paling rendah yaitu $90 \%$ dan paling tinggi $95 \%$. Dan setelah diberikan posisi semifowler dan teknik pursed lips breathing adalah $97.00 \%$, saturasi paling rendah yaitu $95 \%$ dan paling tinggi $98 \%$. Analisis data dilakukan dengan uji Wilcoxon Signed Rank Test didapatkan nilai $p=0.001(p<0.05)$ yang artinya bahwa ada pengaruh pemberian posisi semifowler dan teknik pursed lips breathing terhadap saturasi oksigen pasien dengan PPOK. Dengan demikian, pemberian posisi semifowler dan teknik pursed lips breathing ini dapat menjadi salah satu terapi intervensi keperawatan non invasif yang dapat meningkatkan saturasi oksigen pada pasien PPOK.

\footnotetext{
Abstract

COPD is a disease of the respiratory tract that has symptoms of sputum production, shortness of breath and productive cough. The semi fowler position and pursed lip breathing makes oxygen in the lungs increasing, making it easier to breathe and reducing membrane damage to alveolus due to fluid build-up The purpose of this study was to determine the effect of semi fowler positioning and pursed lips breathing technique on oxygen saturation of patients with COPD.

This research was a pre-experimental quantitative research with One - Group PretestPosttest Design. The research sample uses Non Probability Sampling technique, namely Consecutive Sampling with a sample of 30 people. Then proceed with the Wilcoxon Signed Ranks Test to test the hypothesis.

Based on the results of the study obtained the average oxygen saturation of patients before the administration of semi fowler position and pursed lips breathing technique was $93.10 \%$, the lowest saturation was $90 \%$ and the highest one was $95 \%$. And after being given a semi fowler position and pursed lips breathing technique was $97.00 \%$, the lowest saturation was $95 \%$ and the highest was $98 \%$. Data analysis was done with Wilcoxon Signed Rank Test obtained $p$ value $=0.000(p<0.05)$ which means that there was an effect of semi fowler positioning and pursed lips breathing technique on oxygen saturation of patients with COPD. Thus, the provision of semi fowler positions and pursed lips breathing techniques can be used as one of the non-invasive nursing interventional therapies that can increase oxygen saturation in COPD patients.
} 


\section{PENDAHULUAN}

Seiring dengan perkembangan zaman yang semakin modern dan jumlah penduduk yang terus meningkat, maka pola dan gaya hidup pun semakin beraneka ragam. Salah satu bentuk gaya hidup yang banyak berkembang saat ini adalah kebiasaan merokok dan meningkatnya kepemilikan kendaraan bermotor di kalangan masyarakat. Baik asap rokok maupun gas buang dari kendaraan bermotor tersebut dapat menimbulkan polusi udara di lingkungan masyarakat. Gas buang dari kendaraan tersebut dapat menimbulkan polusi udara sekitar $70-80 \%$, sedangkan asap industri menimbulkan pencemaran udara sekitar 20-30\%. Hal ini diduga menjadi penyebab meningkatnya risiko seseorang terserang penyakit pada saluran pernafasan yang dapat berujung pada Penyakit Paru Obstruktif Kronis (PPOK) (Khasanah, 2015).

Organisasi Kesehatan Dunia (WHO) mencatat tiga juta orang meninggal akibat PPOK pada tahun 2016, dan juga menyatakan bahwa di dua belas negara di wilayah geografis ditemukan prevalensi PPOK sedang hingga berat pada usia 30 tahun ke atas dengan rerata $6,3 \%$. Kota metropolitan dan Singapura memiliki tingkat prevalensi yang rendah sepanjang masa, yaitu $3,5 \%$ dan Vietnam pada $6,7 \%$. Pada tahun 2013, di Amerika Serikat PPOK merupakan penyebab utama kematian ketiga dan lebih dari 11 juta orang sudah dinyatakan menderita PPOK (American Lung Association, 2015). Mengambil tolak ukur dari PLATINO, sebuah riset dilaksanakan pada negara Brasil, Meksiko, Uruguay, Chili dan Venezuela diperoleh hasil hitung kejadian dalam angka PPOK sebesar 14,3\%. PPOK senilai 14,3\% tersebut, dibagi menjadi dua yaitu, pria $(18,9 \%)$ dan wanita sejumlah $11,3 \%$. Kemudian dari sumber uji BOLD, hasil test hampir sama yang dilaksanakan pada 12 negara penggabungan hasil hitung kejadian dalam angka PPOK sejumlah $10,1 \%$, nilai kejadian dalam angka pada pria 11,8\% dan $8,5 \%$ pada perempuan. Sehingga nilai angka kejadian pada pria lebih tinggi dari nilai angka kejadian pada wanita. Bergantung pada informasi dan investigasi Riset Kesehatan Dasar (RISKESDAS) 2013 yang dilakukan di Indonesia, tingkat penyebaran PPOK sejumlah 3,7\%. Terjadinya penyakit ini bertambah seiring peningkatan umur dimana nilai pria $(4,2 \%)$ lebih besar daripada wanita (3,3\%). Pada Provinsi Bali di tahun 2013 nilai kejadian dalam angka PPOK yaitu sebesar 3,5\% (Kementerian Kesehatan RI Provinsi Bali, 2013).

PPOK merupakan kelainan pada organ paru-paru kronis yang memiliki kategoris yaitu adanya kendala pengaliran udara pada sistem penghubung pernapasan yang futuristik nonreversibel atau reversibel parsial, serta adanya respon reaksi tubuh terhadap mikroorganisme, unsur atau gas berbahaya pada paru-paru (Global Initiative for Chronic Obstructive Lung Disease, 2015). Gejala-gejala yang paling umum dari PPOK ialah produksi batuk yang terjadi secara terus menerus, batuk yang menghasilkan dahak serta tidak dapat bernafas dengan lancar. Hal ini timbul dalam rentan waktu lama dan semakin memburuk apabila dibiarkan begitu saja. Menurut Ikawati (2016) pria memilki resiko terjangkit PPOK daripada wanita diakibatkan kebiasaan merokok pada lakilaki namun ada kecenderungan peningkatan prevalensi pada perempuan karena meningkatnya jumlah wanita yang merokok. PPOK terjadi lebih sering pada usia di atas 40 tahun dan memiliki riwayat terpajan faktor risiko PPOK, terutama merokok. Keturunan juga memiliki pengaruh dalam pertumbuhan PPOK. Hal ini paling sering terjadi di sekitar kerabat yang mengalami PPOK. dan perokok daripada antara pengidap PPOK yang merokok tapi menghasilkan keturunan yang tidak mengidap PPOK (Perhimpunan Dokter Paru Indonesia, 2011).

Adapun penatalaksanaan PPOK selama ini yang diberikan pada pasien adalah terapi farmakologi berupa pemberian bronkodilator, anti peradangan dan terapi oksigen. Selain itu dari intervensi 
keperawatan pasien juga diberikan posisi semifowler. Terapi ini mungkin sudah menjadi terapi pilihan selama ini dan terbukti mampu memperbaiki kondisi pasien, namun tindakan saja belum mampu mempercepat perbaikan kondisi pasien sehingga waktu perawatan pasien PPOK cenderung lama, karena pasien tidak diberikan latihan nafas sehingga ketergantungan terhadap oksigen justru meningkat. Oleh karena itu, pasien diberikan terapi tambahan secara non farmakologi berupa terapi latihan pernafasan, salah satunya adalah Pursed Lips Breathing (PDPI, 2016).

Pursed lips breathing ini merupakan salah satu terapi intervensi keperawatan non invasif yang dapat mengurangi sesak napas (menurunkan frekuensi pernapasan), meningkatkan saturasi oksigen dan meningkatkan arus puncak respirasi. Selain itu Pursed lips breathing juga ditujukan untuk memperbaiki pertukaran gas dan penggunaan otot pernapasan, meningkatkan tekanan jalan napas selama ekspirasi, dan mengurangi jumlah udara yang terjebak di dalam paru (Smeltzer \& Bare, 2013).

Melihat peliknya permasalahan pada
pasien dengan PPOK, maka penatalaksanaan yang tepat sangatlah diperlukan. Tujuan penatalaksanaan pada pasien PPOK ini adalah mencegah progresif penyakit, menghilangkan gejala, memperbaiki status kesehatan, menurunkan mortalitas, mencegah dan mengobati eksaserbasi, serta memperbaiki exercise tolerance (Slamet H, dkk, 2013).

Di RS Mangusada prevalensi pasien PPOK murni yang dirawat di rawat inap pada tahun 2019 adalah 41 orang, dan pasien PPOK beserta penyakit lain terdata 60 orang. Pada pasien PPOK yang mengalami eksarsebasi akut yang mengalami penurunan saturasi sampai di bawah $90 \%$ hanya ditangani dengan pemberian oksigen, pemberian posisi fowler dan semifowler serta obat-obatan bronkodilator melalui nebulizer maupun intravena sedangkan latihan pernapasan seperti pursed lip breathing tidak diterapkan pada pasien tersebut. Sehingga peningkatan saturasi oksigen pada pasien PPOK cenderung tidak meningkat. Hal tersebut juga menjadi penyebab waktu perawatan pasien menjadi lama. Oleh karena itu peneliti tertarik melakukan penelitian dengan judul Pengaruh Pemberian Posisi Semifowler dan Teknik Pursed Lips Breathing terhadap Saturasi Oksigen Pasien dengan PPOK.

\section{METODE}

Penelitian ini merupakan jenis penelitian Pre-Experimental design, dikatakan pre-experimental design karena belum merupakan eksperimen sungguhsungguh karena masih terdapat variabel luar yang ikut berpengaruh terhadap terbentuknya variabel dependen. Rancangan ini berguna untuk mendapatkan informasi awal terhadap pertanyaan yang ada dalam penelitian. Design penelitian ini menggunakan bentuk One - Group PretestPosttest Design, desain ini terdapat pre-test sebelum diberi perlakuan dan post-test setelah diberikan perlakuan. Populasi dalam penelitian ini adalah semua pasien PPOK yang dirawat di ruang HCU RSD Mangusada. Jumlah pasien PPOK selama tiga bulan terakir dari bulan Januari-Maret 2020 sebanyak 32 orang, kalau dirataratakan kurang lebih 10 per bulan. Pada penelitian ini penentuan besar sampel menggunakan rumus Slovin (Nursalam, 2016). Dalam penelitian ini peneliti menggunakan teknik Non Probabilty Sampling yaitu Consecutive Sampling, cara pengambilan sampel ini dilakukan dengan memilih sampel yang memenuhi kriteria penelitian sampai kurun waktu tertentu sehingga jumlah sampel terpenuhi (Sugiyono, 2010).

Setelah dilakukan uji normalitas data, karena data berdistribusi tidak normal kemudian dilanjutkan dengan uji Wilcoxon Signed Ranks Test untuk menguji hipotesis. Analisis data dilakukan untuk mengetahui pengaruh pemberian posisi semifowler dan teknik pursed lips breathing terhadap saturasi oksigen pasien dengan PPOK.

\section{HASIL DAN PEMBAHASAN}


HASIL

Penelitian dilaksanakan di ruang HCU RSD Mangusada pada bulan OktoberDesember 2020.

Tabel 1

Distribusi Frekuensi Jenis Kelamin pada Pasien PPOK

\begin{tabular}{lcc}
\hline Jenis Kelamin & Frekuensi (f) & $\begin{array}{c}\text { Persentase } \\
(\%)\end{array}$ \\
\hline Laki-laki & 17 & 56.7 \\
\hline Perempuan & 13 & 43.7 \\
\hline Total & 30 & 100 \\
\hline
\end{tabular}

Pada Tabel 1 dapat dilihat bahwa mayoritas responden berjenis kelamin lakilaki.

Tabel 2

Distribusi Frekuensi Umur pada pasien PPOK $(n=30)$

\begin{tabular}{lcc}
\hline Keterangan & Mean & $\begin{array}{c}\text { Median } \\
\text { (Min-Max })\end{array}$ \\
\hline Umur & 53.13 & $\begin{array}{c}55 \\
(40-65)\end{array}$ \\
Responden & & \\
\hline
\end{tabular}

Berdasarkan Tabel 2 dapat dilihat bahwa Rata-rata Usia Pasien PPOK yang Dirawat Di Ruang HCU RSD Mangusada yaitu paling kecil 40 tahun dan paling besar 65 tahun.

Tabel 3

Distribusi Frekuensi Pendidikan pada pasien PPOK

\begin{tabular}{|ccc|}
\hline Pendidikan & $\begin{array}{c}\text { Frekuensi } \\
(\mathrm{f})\end{array}$ & $\begin{array}{c}\text { Persentase } \\
(\%)\end{array}$ \\
\hline SD & 8 & 26.7 \\
SMP & 8 & 26.7 \\
SMA & 11 & 36.7 \\
S1 & 3 & 10.0 \\
\hline Total & 30 & 100 \\
\hline
\end{tabular}

Berdasarkan tabel 3 pendidikan responden mayoritas berjenjang SMA dengan persentase $36.7 \%$.
Tabel 4

Distribusi Frekuensi Jenis Oksigenasi pada Pasien PPOK

\begin{tabular}{|l|c|c|}
\hline Jenis Oksigen & $\begin{array}{c}\text { Frekuensi } \\
\text { (f) }\end{array}$ & $\begin{array}{c}\text { Persentase } \\
(\%)\end{array}$ \\
\hline O2 NRM 10 Lpm & 2 & 6.7 \\
\hline O2 NRM 12 LPM & 4 & 13.3 \\
\hline O2 NRM 15 LPM & 1 & 3.3 \\
\hline O2 SM 10 LPM & 5 & 16.7 \\
\hline O2 SM 5 LPM & 7 & 23.3 \\
\hline 02 SM 6 LPM & 5 & 16.7 \\
\hline O2 SM 8 LPM & 6 & 20.0 \\
\hline Total & $\mathbf{3 0}$ & $\mathbf{1 0 0 . 0}$ \\
\hline
\end{tabular}

Berdasarkan tabel 4 jenis oksigenasi yang didapatkan pasien lebih banyak menggunakan O2 Simple Mask 5 lpm dengan persentase $23.3 \%$.

Tabel 5

Perbedaan Rata-rata Saturasi Oksigen

Sebelum dan Setelah Diberikan Posisi

Semifowler dan teknik Pursed Lips

Breathing

\begin{tabular}{|l|l|l|l|}
\hline Ket & Mean \pm SD & $\begin{array}{l}\text { Median } \\
\left(\begin{array}{l}\text { min- } \\
\text { max })\end{array}\right.\end{array}$ & 95\%CI \\
\hline $\begin{array}{l}\text { Saturasi } \\
\text { Oksigen } \\
\text { Pre-test }\end{array}$ & $93.10 \pm 1.539$ & $\begin{array}{l}93.00 \\
(90-95)\end{array}$ & $\begin{array}{l}92.53- \\
93.67\end{array}$ \\
\hline $\begin{array}{l}\text { Saturasi } \\
\text { Oksigen } \\
\text { Post-test }\end{array}$ & $97.00 \pm 0.947$ & 97.00 & $96.65-$ \\
\hline
\end{tabular}

Berdasarkan tabel 5 dapat diketahui bahwa rata-rata nilai saturasi oksigen pada pasien PPOK sebelum dilakukan teknik pursed lips breathing dengan posisi semifowler adalah $93.10 \%$ dengan standar deviasi 1.539 . Nilai rata-rata saturasi oksigen pada pasien PPOK setelah dilakukan teknik pursed lips breathing dengan posisi semifowler adalah $97.00 \%$ dengan standar deviasi 0.947 .

Setelah dilakukan uji normalitas data, karena data berdistribusi tidak normal dilanjutkan dengan uji Wilcoxon Signed Ranks Test untuk menguji hipotesis. Analisis data dilakukan untuk mengetahui pengaruh pemberian posisi semifowler dan teknik pursed lips breathing terhadap saturasi oksigen pasien dengan PPOK, 
adapun hasil analisis dengan menggunakan uji Wilcoxon Signed Ranks Test, seperti terdapat pada tabel di bawah ini.

Tabel 6

Hasil Uji Wilcoxoxn Signed Rank Test Sebelum dan Sesudah Diberikan Posisi Semifowler dan Teknik Pursed Lips Breathing

\begin{tabular}{|c|c|c|c|c|c|c|}
\hline \multirow[t]{2}{*}{ Ket } & \multirow[t]{2}{*}{$\mathrm{n}$} & \multirow{2}{*}{$\begin{array}{l}\text { Rata } \\
\text {-rata }\end{array}$} & \multicolumn{2}{|c|}{$95 \% \mathrm{CI}$} & \multirow[t]{2}{*}{$\mathrm{Z}$} & \multirow[t]{2}{*}{$\mathrm{P}$} \\
\hline & & & $\begin{array}{c}\text { Lowe } \\
\mathrm{r}\end{array}$ & $\begin{array}{c}\text { Uppe } \\
\text { r }\end{array}$ & & \\
\hline $\begin{array}{l}\mathrm{SpO} \\
2 \\
\text { Pre } \\
\text { test }\end{array}$ & $\begin{array}{l}3 \\
0\end{array}$ & $\begin{array}{c}93.1 \\
0\end{array}$ & 92.53 & $\begin{array}{c}93.6 \\
7\end{array}$ & \multirow{2}{*}{$\begin{array}{l}- \\
4.821 \\
\mathrm{~b}\end{array}$} & \multirow{2}{*}{$\begin{array}{l}0.00 \\
1\end{array}$} \\
\hline $\begin{array}{c}\text { SpO } \\
2 \\
\text { Post } \\
\text { test }\end{array}$ & $\begin{array}{l}3 \\
0\end{array}$ & $\begin{array}{c}97.0 \\
0\end{array}$ & 96.65 & $\begin{array}{c}97.3 \\
5\end{array}$ & & \\
\hline
\end{tabular}

Dari tabel 6 berdasarkan hasil uji Wilcoxon Signed Ranks Test pada tabel di atas, didapatkan nilai $\mathrm{p}$ value $=0,001(\mathrm{p}<0,05)$ pada saturasi oksigen pasien PPOK setelah dilakukan teknik pursed lips breathing dengan Posisi semifowler yang berarti $\mathrm{Ha}$ diterima, dimana secara statistic nilai $\mathrm{Z}$ hitung bernilai sebesar $-4.821 \mathrm{~b}$ hal ini menunjukkan adanya pengaruh yang signifikan antara pemberian posisi semifowler dan teknik pursed lips breathing terhadap saturasi oksigen pasien dengan PPOK.

\section{PEMBAHASAN}

\section{Saturasi Oksigen Sebelum Pemberian Posisi Semifowler dan Teknik Pursed Lips Breathing}

Berdasarkan hasil penelitian didapatkan rata-rata saturasi oksigen pasien sebelum pemberian posisi semifowler dan teknik pursed lips breathing adalah 93.10\%, saturasi paling rendah yaitu $90 \%$ dan paling tinggi $95 \%$.

Smeltzer et al, (2013), mengatakan bahwa PPOK adalah kondisi yang tidak dapat diubah yang digambarkan kesulitan mengalirkan udara ke dalam tubuh saat melakukan gerakan serta gangguan keluar masuknya udara pada paru-paru. PPOK ialah kelainan kronis dengan kondisi terganggunya sistem aliran udara akibat sumbatan aliran nafas oleh radiasi dari asap rokok dan polusi udara kotor dalam kurun waktu yang tidak singkat. Kelainan pada paru-paru dengan kurun waktu yang tidak sebentar biasanya disebut PPOK. (Grace et al, 2011). Mansjoer (2011) dan Ovedoff (2010) menyatakan bahwa penyebab terjadinya PPOK yaitu: kebiasaan merokok, polusi udara, umur dan gender mengakibatkan melemahnya gerakan dari organ paru, peradangan saluran nafas yang buruk seperti pneumonia, bronchitis dan terganggunya proses menghirup udara ke dalam tubuh pada seseorang pada keadaan tersebut rawan terjangkit kelainan PPOK, kemudian kondisi melemahnya alfa anti tripsin. Zat dalam tubuh ini memproteksi organ paru untuk terhindar dari kondisi radang. Memburuknya zat ini membuat seorang terkena empisema walau umur/usia belum memasuki usia tua walaupun yang bersangkutan bukan merupakan perkokok aktif.

Ketiga teori tersebut sesuai dengan penelitian yang dilakukan oleh Niko, dkk (2017), tentang Efektifitas Posisi Semifowler Dengan Pursed Lips Breathing dan Semifowler Dengan Diagphragma Breathing terhadap Saturasi O2 Pasien TB Paru Di RSP Dr. Ariowirawan Salatiga. Penelitian ini menunjukkaan hasil sebelum diberikan posisi semifowler dengan pursed lips breathing nilai rata-rata saturasi oksigennya yaitu $94 \%$. Sedangkan saturasi oksigen responden yang diberikan posisi semifowler dengan diaphragma breathing rata-rata memiliki nilai saturasi oksigen 94\%. Penelitian serupa juga dilakukan oleh Evika, dkk (2020), tentang Perbedaan Nilai Saturasi Oksigen Pasien PPOK Menggunakan Pursed Lips Breathing dan 6 Minutes Walk Exercise, hasil penelitian menunjukkan sebelum diberikan Pursed Lips Breathing dan 6 Minutes Walk 
Exercise nilai saturasi oksigen pasien ratarata $95.39 \%$.

Berdasarkan fakta di atas dengan hasil penelitian yang dilakukan di Ruang HCU RSD Mangusada Badung, bahwa ratarata responden mengalami PPOK derajat ringan. PPOK disebabkan karena beberapa factor salah satunya adalah factor usia dan jenis kelamin. Rata-rata jenis kelamin responden yaitu berjenis kelamin laki-laki, hal ini dapat dijelaskan bahwa laki-laki lebih beresiko terkena PPOK daripada wanita. Kondisi ini terkait dengan kebiasaan merokok pada pria. Semakin tinggi derajat merokok seseorang, maka akan semakin banyak orang tersebut terpapar berbagai zat yang dianggap toksik oleh tubuh pada saluran pernafasan yang akan berujung kepada penurunan fungsi faal paru yang lebih cepat dibanding bukan perokok. Kemudian faktor berikutnya adalah usia, rata-rata usia responden mayoritas > 50 tahun, dengan bertambahnya usia terjadi perubahan anatomi yang telah mempengaruhi fungsi pulmonal. Perubahan anatomis seperti komplikasi paru dan dinding dada turut berperan dalam penurunan kerja pernafasan sekitar $20 \%$ pada lanjut usia. Kemudian adanya penurunan kekuatan otot-otot pernafasan dapat meningkatkan risiko keletihan otototot pernafasan pada lansia. Perubahanperubahan tersebut turut berperan dalam penurunan konsumsi oksigen maksimum. Perubahan-perubahan pada intertisium parenkim dan penurunan pada daerah permukaan alveolar dapat menghasilkan penurunan difusi oksigen. Dengan adanya peningkatan metabolisme yang membutuhkan oksigen maksimum juga akan mempengaruhi peningkatan jumlah karbondioksida yang dikeluarkan. Hal ini menghasilkan peningkatan kecepatan respirasi dan terjadi dyspnea.

\section{Saturasi Oksigen Setelah Pemberian Posisi Semifowler dan Teknik Pursed Lips Breathing}

Berdasarkan hasil penelitian didapatkan rata-rata saturasi oksigen pasien setelah pemberian posisi semifowler dan teknik pursed lips breathing adalah $97.00 \%$, saturasi paling rendah yaitu $95 \%$ dan paling tinggi $98 \%$.

Menurut GOLD (2017), PPOK merupakan penyakit yang dapat dicegah dan diringankan baik dengan pengobatan maupun dengan program latihan. Pencegahan dan pengobatan PPOK tidak hanya dilakukan oleh tenaga kesehatan saja tetapi juga dapat dilakukan oleh pasien dengan cara melakukan perawatan diri sendiri (self care) yang di ajarkan oleh perawat atau tenaga kesehatan lainnya baik dengan atau tanpa pendampingan dari keluarga. Vestbo et.al. (2013) menyatakan bahwa, PPOK adalah penyakit yang dapat dicegah dan diobati yang secara umum ditandai dengan keterbatasan aliran udara yang terus-menerus biasanya progresif dan berhubungan dengan peradangan kronis, peningkatan respon dalam saluran udara dan paru-paru dari partikel berbahaya atau gas.

Kedua teori tersebut sesuai dengan penelitian yang dilakukan oleh Niko, dkk (2017), tentang "Efektifitas Posisi Semifowler Dengan Pursed Lips Breathing dan Semifowler Dengan Diagphragma Breathing terhadap Saturasi Oksigen Pasien TB Paru Di RSP Dr. Ariowirawan Salatiga”. Penelitian ini menunjukkaan hasil setelah diberikan posisi semifowler dengan pursed lips breathing nilai rata-rata saturasi oksigen pasien yaitu 97\%. Sedangkan saturasi oksigen responden yang diberikan posisi semifowler dengan diaphragma breathing nilai rata-ratanya yaitu $96 \%$. Penelitian serupa juga dilakukan oleh Evika, dkk (2020), tentang "Perbedaan Nilai Saturasi Oksigen Pasien PPOK Menggunakan Pursed Lips Breathing dan Six Minutes Walk Exercise", hasil penelitian menunjukkan setelah diberikan pursed lips breathing dan six minutes walk Exercise nilai saturasi oksigen pasien rata-rata $98.08 \%$.

Berdasarkan fakta di atas dengan hasil penelitian yang dilakukan di Ruang HCU RSD Mangusada menunjukkan 
perubahan hasil pada pengukuran saturasi oksigen setelah pemberian posisi semifowler dan teknik pursed lips breathing yang dilakukan 3 kali sehari yaitu pada pagi, siang, sore/malam hari dengan teknik latihan satu kali yang diulang 4-5 kali dengan istirahat selama satu menit dengan durasi waktu dalam sekali latihan 15 menit dan dilakukan selama 3 hari berturut-turut.

\section{Pengaruh Pemberian Posisi Semifowler dan Teknik Pursed Lips Breathing terhadap Saturasi Oksigen pada Pasien PPOK}

Setelah dilakukan uji Wilcoxon Signed Rank Test seperti pada tabel 5.6, didapatkan nilai $\mathrm{p}=0.001(\mathrm{p}<0.05)$ pada saturasi oksigen pasien yang berarti $\mathrm{Ha}$ diterima. Jadi ada peningkatan saturasi oksigen pasien PPOK sebelum dan setelah diberikan posisi semifowler dengan teknik pursed lips breathing. Sehingga dapat dikatakan bahwa ada pengaruh pemberian posisi semifowler dan teknik pursed lips breathing terhadap saturasi oksigen pasien dengan PPOK.

Hal ini sesuai dengan penelitian yang dilakukan oleh Niko, dkk (2017) tentang Efektifitas Posisi Semifowler dengan Pursed Lips Breathing dan Semifowler dengan Diagphragma Breathing terhadap Saturasi O2 Pasien TB Paru Di RSP Dr. Ariowirawan Salatiga. Hasil penelitian pembanding menunjukkan nilai $\mathrm{p}$-value $=0.020(\mathrm{p}>0.05)$ sehingga dapat disimpulkan bahwa posisi semifowler dengan pursed lips breathing lebih efektif dibandingkan dengan semifowler dengan diapragma breathing. Hasil penelitian serupa juga didapatkan pada penelitian Evika, dkk (2020) tentang Perbedaan Nilai Saturasi Oksigen Pasien PPOK Menggunakan Pursed Lip Breathing dan Six Minutes Walk Exercise, hasil penelitian menunjukkan nilai $\mathrm{p}$-value $=0.001(\mathrm{p}>$ 0.05 ) yang berarti bahwa terdapat pengaruh tindakan pursed lips breathing dan six minutes walk exercise terhadap peningkatan nilai saturasi oksigen pada pasien PPOK derajat ringan.

Penatalaksanaan PPOK secara umum ada 6 jenis yaitu: edukasi, terapi stimulan, $\mathrm{O}_{2}$, aliran udara mekanis, zat makanan dan yang terakhir pemulihan, kemudian penatalaksanaan keperawatan ada 5 jenis diantaranya: mempertahankan patensi jalan nafas, membantu tindakan untuk mempermudah pertukaran gas, meningkatkan masukan nutrisi, mencegah komplikasi, memperlambat memburuknya kondisi dan memberikan informasi tentang proses penyakit/prognosis dan program pengobatan. Penatalaksanaan secara umum salah satunya rehabilitasi yaitu bertujuan untuk meningkatkan kualitas hidup dan toleransi pasien PPOK terhadap aktifitas fisik yaitu: menyesuaikan aktifitas, latihan batuk efektif dan latihan pernafasan. Latihan pernafasan dalam penatalaksanaan pasien dengan PPOK yaitu salah satunya dengan teknik pursed lips breathing (PLB) adalah latihan nafas dengan penekanan pada saat ekspirasi bertujuan dalam memudahkan pengeluaran udara air trapping atau udara yang terjebak oleh saluran nafas. PLB dapat menghambat udara keluar dengan menggunakan kedua bibir sehingga menyebabkan tekanan dalam rongga mulut menjadi lebih positif. Keberhasilan PLB yaitu melakukan latihan dengan keadaan santai.

Pursed lips breathing membantu mengeluarkan udara yang terperangkap pada pasien PPOK sehingga $\mathrm{CO} 2$ di paru dapat dikeluarkan. Mengeluarkan Karbon Dioksida pada organ paru membuat peluang dominan Oksigen lebih besar untuk mengisi ruang alveolus. Apalagi jika bernafas menggunakan teknik pursed lips breathing ada tata cara inspirasi yang lebih dalam dan kuat, maka cara/sistem ini menolong tambahan/masukkan $\mathrm{O} 2$ ke alveolus. Tingginya tekanan $\mathrm{O} 2$ di alveolus dibandingkan dengan tekanan $\mathrm{O} 2$ di kapiler paru dan rendahnya tekanan $\mathrm{CO} 2$ di alveolus dibandingkan dengan tingginya tekanan $\mathrm{CO} 2$ di kapiler paru menyebabkan meningkatnya gradient tekanan gas-gas 
tersebut di antara kedua sisi. Perbedaan gradient tekanan $\mathrm{O} 2$ yang tinggi meningkatkan pertukaran gas, yaitu difusi O2 dari alveolus ke kapiler paru. Perbedaan tekanan $\mathrm{CO} 2$ yang tinggi juga meningkatkan pertukaran gas, yaitu difusi $\mathrm{CO} 2$ dari kapiler paru ke alveolus untuk selanjutnya dikeluarkan ke atmosfir (Khasanah, 2015).

Adanya pengaruh pemberian posisi semifowler dan teknik pursed lips breathing terhadap saturasi oksigen pasien dengan PPOK, sebagian besar disebabkan karena teraturnya responden mengikuti latihan pursed lips breathing dengan posisi semifowler sebanyak tiga kali sehari pada pagi, siang dan sore/malam selama tiga hari berturut-turut dengan waktu latihan satu kali dan diulang 4-5 kali kemudian istirahat satu menit, dengan durasi waktu sekali latihan yaitu selama 15 menit. Teknik pursed lips breathing bertujuan dalam menolong pasien dalam mentransportasi udara, melaksanakan induksi bentuk nafas perlahan serta panjang, melakukan pertolongan kepada pasien agar mengendalikan proses menghirup oksigen, mengantisipasi agar pasien tidak pingsan dan melaksanakan latihan otot ekspirasi untuk memanjangkan ekshalasi, meningkatkan tekanan aliran nafas saat proses ekspirasi dan mengurangi tertutupnya udara pada pernafasan. posisi semifowler juga berperan dalam mengatasi masalah pernafasan, posisi semifowler mengandalkan gaya gravitasi untuk membantu melancarkan jalan nafas menuju ke paru sehingga oksigen akan mudah masuk. Hal ini dapat meningkatkan oksigen yang diisnpirasi atau dihirup pasien. Dengan meningkatnya oksigen dalam tubuh, mengikat pula oksigen yang dibawa sel darah merah dan hemoglobin, sehingga saturasi oksigen juga ikut meningkat (Muttaqin, 2012).

\section{KESIMPULAN}

\section{Simpulan}

Berdasarkan hasil analisis pembahasan tentang pengaruh pemberian posisi semifowler dan teknik pursed lips breathing terhadap saturasi oksigen pasien dengan PPOK di ruang HCU RSD Mangusada Kabupaten Badung yang telah diuraikan sebelumnya, dapat disimpulkan sebagai berikut.

1. Sebelum pemberian posisi semifowler dan teknik pursed lips breathing pada pasien dengan PPOK rata-rata saturasi oksigen pasien $93.10 \%$.

2. Terjadi peningkatan saturasi oksigen pasien sebelum dan setelah pemberian posisi semifowler dan teknik pursed lips breathing terhadap saturasi oksigen pasien dengan nilai rata-rata $97.00 \%$.

3. Terdapat pengaruh pemberian posisi semifowler dan teknik pursed lips breathing yang signifikan terhadap saturasi oksigen pasien dengan PPOK dengan nilai $\mathrm{p}$-value $=$ $0.001(\mathrm{p}<0.05)$.

\section{Saran}

Diharapkan Rumah Sakit Daerah Mangusada Kabupaten Badung dapat mengaplikasikan pemberian teknik pursed lips breathing dan posisi semifowler terhadap pasien sesak napas dengan gangguan respirasi untuk mengurangi sesaknya sehingga dapat memberikan pelayanan kesehatan dan mempertahankan hubungan kerja yang baik antara tim kesehatan maupun klien sehingga dapat meningkatkan mutu pelayanan asuhan keperawatan yang optimal pada umumnya.

Hasil penelitian ini diharapkan bisa digunakan sebagai bahan acuan dan masukan untuk peneliti selanjutnya dengan melibatkan variable bebas yaitu posisi semifowler dan teknik pursed lips breathing serta jenis dan design penelitian yang lebih baik lagi dengan melibatkan kelompok kontrol sebagai pembanding dalam penelitian tentang pemberian posisi semifowler dan teknik pursed lips breathing. Diharapkan juga kepada peneliti selanjutnya agar meneliti karakteristik responden khususnya terkait kondisi kebiasaan merokok dan pekerjaan responden. Serta peneliti selanjutnya diharapkan mampu menyamakan jenis oksigenasi yang diberikan kepada responden. 


\section{DAFTAR PUSTAKA}

American Lung Association, 2015. Lung Disease.

http://www.Lung.Org/Lung-

Disease/COPD/In-Depth-

Resources/- FactSheet.Html

Diakses pada tanggal 25 Maret pukul 18.00 wita

Badan Penelitian dan Pengembangan Kesehatan Kementerian Kesehatan RI. Laporan Hasil Riset Kesehatan Dasar (RISKESDAS) 2013. LITBANG DEPKES RI. Jakarta. 2013.

Brunner \& Suddarth, 2014. Keperawatan Medikal Bedah. Edisi 8. Jakarta : EGC

Buist, AS, McBurnie MA, Vollmer WM, Gillespie S, Burney P, Mannino DM, Manezes AM, Sullivan SD, Lee TA, Weiss KB, Jensen RL, Marks GB, Gulsvik A, Nizankowska-Mogilnicka E; BOLD Collaborative Research Group, International variation in the prevalence of COPD (the BOLD Study): a population-based prevalence study, Lancet : 2007 Sep 1;370(9589):741-50.

Chan-Yeung M, Ait Khaled N, White N, Ip MS, and Tan WC, The Burden and Impact of COPD in Asia and Africa, Int $\mathrm{J}$ Tuberc Lung Dis, 2004; 8; p.2-14

Dinas Kesehatan Provinsi Bali. Profil Kesehatan Provinsi Bali. 2016;282. Available from: http://www.depkes.go.id/resources /download/profil/PROFIL_KES_P ROVINSI 2012/17 Profil Kes.Pr ov.Bali_2012.pdf

Diakses pada tanggal 15 april pukul 15.00 wita
Frank J.Visser, Sunil Ramlal, P.N. Richard Dekhuijzen, Yvonne F.Heijdra (2010) dengan judul "Pursed Lips Breathing Improves Inspiratory Capacity in Chronic Obstructive Pulmonary disease: clinical investigations". Karger AG, Basel. Respiration 2011;81:372-378. DOI:10.1159/000319036.

GOLD. Global Initiative for Chronic Obstructive Lung Disease Global Strategy For The Diagnosis, Management, And Prevention Of Chronic Obstructive Pulmonary Disease Updated 2016.

Grace, et.all. 2011. Ata Glace Lima Bedah. Edisi 3. Yogyakarta: PT. Gelora Aksara Pratama.

Guyton AC, Hall JE. Buku Ajar Fisiologi Kedokteran. Jakarta; 2012.

Jackson, D. 2014. Keperawatan Medikal Bedah Edisi 1. Yogyakarta: Rapha Pubising.

Khasanah, suci \& Maryoto, Madiyo. (2014). Efektifitas Posisi Condong Ke Depan (Ckd) Dan Pursed Lips Breathing (Plb) Terhadap Peningkatan Saturasi Oksigen Pasien Penyakit Paru Obstruktif Kronik (Ppok). http://jurnal.unimus.ac.id/index.ph p/psn12012010/article/vie w/1200, Diakses tanggal 4 april 2020 pukul 20.00 wita

Kozier B, ERB G, Berman A, Synder SJ. Buku Ajar Fundamental Keperawatan Konsep, Proses \& Praktik. Jakarta; 2011.

Menezes AMB, Perez-Padilla R, Jardim JB, Muiño A, Lopez MV, Valdivia G, et al. Chronic obstructive pulmonary disease in five Latin 
American cities (the PLATINO study): a prevalence study. The Lancet. 2005;366(9500):1875-81.

Nursalam.(2013). Metodologi penelitian ilmu keperawatan pendekatan praktis (Edisi 3).Jakarta: Salemba Medika

Nursalam. (2014). Manajemen Keperawatan Aplikasi dalam Praktik Keperawatan Profesional Edisi 4. Jakarta: Salemba Medika

Persatuan Dokter Paru Indonesia, 2011. Penyakit Paru Obstruktif Kronik : Pedoman \& Penatalaksanaan Di Indonesia

Potter, P.A \& Perry A.G. (2009). Fundamental of Nursing. Jakarta : EGC

Potter, P A \& Perry, A G. 2010. Buku Ajar Fundamental Keperawatan: Konsep, Proses, dan Praktik Edisi 4 Volume 2.EGC: Jakarta

Qamila, Barakatul, dkk (2019). Efektivitas Teknik Pursed Lips Breathing pada Pasien Penyakit Paru Obstruksi Kronik (PPOK) : Study Sistematic Review

Septia N, Wungouw H, Doda V. Hubungan merokok dengan saturasi oksigen pada pegawai di fakultas kedokteran universitas Sam Ratulangi Manado. J eBiomedik [Internet]. 2016;4(2):27. Available from: https://ejournal.unsrat.ac.id/index. php/ebiomedik/article/view/14611/ $\underline{14179}$

Diakses pada tanggal 18 Maret 2020 pukul 21.00 WITA

Sinambela AH, Dkk. Pengaruh Latihan Fisik Terhadap Saturasi Oksigen pada Penderita Penyakit Paru
Obstruktif Kronik Stabil. 2015;35(3).

Slamet H, dkk, (2013). Buku Ajar Ilmu Penyakit paru. Departemen Ilmu Penyakit Paru, FK Unair RSUD Dr. Soetomo. Surabaya.

Smeltzer, S.C., Bare, G.B. (2013). Buku Ajar Keperawatan Medikal Bedah. (Edisi 8 Volume.1). Alih Bahasa: Waluyo, A., dkk, Jakarta; EGC.

Sugiyono. (2015). Metode Penelitian Kuantitatif Kualitatif R\&B. Bandung: Aflabeta.

Wikipedia Indonesia, (2012). Penyakit paru obstruksi kronik. http://id.wikipedia.org/wiki/Penya kit_paru_obstruktif_kronik, Diakses pada tanggal 20 April 2020 pukul 20.00 WITA

World Health Organization (WHO). Chronic Obstructive Pulmonary Disease (COPD). WHO. Geneva. 2013.

The Top 10 Causes of Death, Global Health Estimates, 2016

https://www.who.int/newsroom/fact-sheets/detail/the-top-10causes-of-death, Diakses pada tanggal 2 april 2020 pukul 19.00 wita 